\title{
POLA PEMBENTUKAN KARAKTER MANDIRI PADA PONDOK PESANTREN DARUSSALAM MEKAR AGUNG DESA PUCANGANOM, KECAMATAN KEBONSARI, KABUPATEN MADIUN TAHUN 2015
}

\section{Dadang Setyawan*}

\begin{abstract}
Abstrak
ola pembentukan karakter mandiri saat ini merupakan hal yang sangat

$\mathrm{P}$ penting untuk anak-anak sebagai calon penerus bangsa. Pada pondok pesantren, saat santri masuk sudah dikenalkan dengan kemandirian. Penelitian ini bertujuan untuk mengetahui pola pembentukan karakter mandiri pada pondok pesantren Darussalam Mekar Agung di Desa Pucanganom, Kecamatan Kebonsari, Kabupaten Madiun.Metode penelitian ini yaitu deskriptif kualitatif. Penelitian ini dilaksanakan di Pondok Pesantren Darussalam Mekar Agung Desa Pucanganom, Kecamatan Kebonsari, Kabupaten Madiun selama empat bulan, yaitu Maret sampai Juni 2015. Teknik pengumpulan data dengan observasi, wawancara, dan dokumentasi. Teknik analisis data menggunakan analisis data interaktif yaitu reduksi data, penyajian data, dan penarikan kesimpulan dan verifikasi. Hasil penelitian menunjukkan bahwa Pondok Pesantren Darussalam Mekar Agung sangat berperan dalam pembentukan karakter mandiri santri. Hal ini ditunjukkan dengan berjalannya kegiatan para santri yang semuanya dikerjakan sendiri tanpa bantuan dari orang tua. Selain itu, didukung dengan ketatnya aturan pondok pesantren yang menambah terbentuknya karakter mandiri pada santri.
\end{abstract}

Kata Kunci: Karakter, Mandiri, Pondok Pesantren

* Mahasiswa Prodi PPKn IKIP PGRI Madiun 
PENDAHULUAN

Pada dunia pendidikan, banyak dibicarakan tentang pendidikan karakter. Munculnya pendidikan karakter sebagai wacana baru pendidikan nasional bukan merupakan fenomena yang mengejutkan sebab perkembangan sosial politik dan kebangsaan cenderung menghasilkan karakter bangsa. Maraknya perilaku anak yang selalu menggantungkan dirinya pada orang lain sangat tidak baik untuk kepribadian anak kedepannya. Hal lainnya yaitu orang tua yang terlalu memanjakan anak dan selalu menuruti yang diminta oleh anak, anak terbiasa dengan bantuan pengasuh sehingga anak menjadi tidak mandiri hingga dewasa. Dunia pendidikan dinilai hanya mampu melahirkan lulusan-lulusan manusia dengan tingkat intelektual yang memadai tetapi terkadang sebagian nilai diperoleh dengan cara yang tidak murni. Tidak sedikit pula diantara mereka yang cerdas tetapi justru tidak memiliki perilaku yang cerdas. Fenomena ini jelas menimbulkan kekhawatiran tersendiri bagi banyak kalangan. Karakter merupakan sifat kejiwaan atau tabiat seseorang yang membedakannya dengan orang lain. Negara Kesatuan Republik Indonesia memiliki Undang-undang yang mengatur segala yang berkaitan dengan dunia pendidikan. Salah satunya adalah Undang-undang Sistem Pendidikan Nasional No. 20 Tahun 2003 Tentang Sistem Pendidikan Nasional: Pasal 3.

Betapa pentingnya membentuk dan membina karakter mandiri para siswa sebagai generasi penerus bangsa. Sejumlah ahli pendidikan mencoba untuk merumuskan konsep tentang pendidikan karakter bahkan sudah melangkah jauh dalam mempraktikkannya. Hal ini perlu dilakukan agar(umat Islam, yang merupakan mayoritas warga bangsa ini) tidak asing lagi dengan tradisi keilmuannya sendiri. Pesantren adalah lembaga yang dikatakan merupakan wujud proses wajar perkembangan sistem pendidikan nasional. Pondok pesantren merupakan salah satu lembaga pendidikan nonformal yang tersebar di Indonesia.Pondok pesantren lahir di tengah-tengah masyarakat.Setiap pondok pesantren memiliki ciri khas 
yang berbeda-beda bergantung dari tipe reader ship dan metodenya yang diterapkan dalam pembelajarannya. Dasar konstitusional pendidikan pesantren adalah Pasal 26 Ayat 1 Bab 4 Undang-undang Nomor 20 Tahun 2003 tentang Sistem Pendidikan Nasional.

$\begin{array}{llr}\text { Karakter } & \text { mandiri } & \text { adalah } \\ \text { perilaku } & \text { untuk } & \text { tidak }\end{array}$
menggantungkan diri kepada orang lain. Menurut KH. Marzuki Wahid (dalam Octavia dkk, 2014: 215) mandiri atau kemandirian dalam ponpes adalah suatu yang penting untuk membina pribadi yang tangguh dan siap pakai, ini yang kami tanamkan pada santri agar mereka lebih siap tempur di tengah masyarakat, termasuk menghadapi berbagai tantangannya, bukan menjadi pribadi yang cengeng.

Mandiri atau kemandirian tidak otomatis tumbuh dalam diri seorang anak. Mandiri pada dasarnya merupakan hasil dari proses pembelajaran yang berlangsung lama. Mandiri tidak selalu berkaitan dengan usia. Bisa saja seorang anak sudah memiliki sifat mandiri karena proses latihan atau karena faktor kehidupan yang memaksanya untuk mandiri (dalam Ngainun Naim, 2012: 162).

Berbagai pengalaman yang telah dilalui pada usia-usia sebelumnya makin mematangkan karakter anak sehingga akan membawa anak pada kemandirian. Kemandirian ini ditandai dengan kesiapan dalam menerima risiko sebagai konsekuensi tidak menaati aturan (dalam A. Masjid dan Andayani, 2012: 26).

Proses pembentukan karakter mandiri berawal dari pembentukan kemandirian akal. Akal merupakan penentu awal dari pembentukan karakter. Untuk dapat membentuk akal mandiri, guru sebagai ujung tombak pendidikan harus melakukan hal-hal berikut ini Menjadi teladan dalam hal kemandirian bagi siswanya. Secara rutin menyampaikan pesan-pesan kemandirian dalam bentuk materi aja yang terintegrasi dengan mata pelajaran yang sudah ada. Dan dalam konteks pengembangan karakter mandiri, guru perlu menyampaikan sejarah atau profil orang-orang yang memiliki karakter mandiri. Dengan kegiatan ini, diharapkan siswa dapat lebih termotivasi untuk menjadi 
insan yang mandiri (Subang Gemilang: 2011: 1).

Karakter mandiri di pondok pesantren sangat diperlukan karena di dalam pondok pesantren para santri jauh dari keluarga dan harus tinggal bersama teman-temannya. Faktor yang mempengaruhi karakter mandiri adalah faktor dari diri sendiri, faktor keluarga, faktor teman dan faktor lingkungan yang berhadapan langsung dengan santri. Bentuk-bentuk karakter mandiri dapat diwujudkan dengan mampu mengatur dirinya sendiri dalam bidang emosi, sosial, intelektual dan ekonomi. Proses pembentukan karakter di pondok pesantren salah satunya dengan pemberian hukuman atau sanksi bagi santriwan-santriwati yang melanggar aturan. Hukuman atau sanksi yang ada dipondok pesantren tidak ada yang menggunakan kekerasan atau melukai fisik.

Karakter santriwan-santriwati di dalam pondok pesantren berbedabeda karena mereka berasal dari keluarga yang berbeda-beda pula sehingga tingkat kemandiriannyapun berbeda. Ada yang sudah mandiri sebelum masuk pondok tetapi ada juga yang baru mandiri sejak berada didalam pondok pesantren. Pembelajaran karakter mandiri dipondok pesantren dibentuk melalui beberapa cara. Dapat dicontohkan dengan menyuci baju sendiri, membersihkan kamar sendiri, memasak sendiri bagi santri yang sudah dewasa.Selain itu, pondok pesantren juga menyediakan kegiatan yang dapat membentuk karakter mandiri santri misalnya seperti memelihara lele, memelihara sawah, memelihara ternak sapi dan ekstrakulikuler yang dapat dijadikan latihan oleh para santri sehingga santri dapat mandiri dalam kehidupannya kelak dalam mencari penghasilan. Jadi pondok pesanteri tidak hanya mengajarkan tentang pelajaran agama namun juga mengajarkan keterampilan berusaha kepada santri.

\section{METODE PENELITIAN}

Berdasarkan masalah penelitian metode penelitian yang digunakan di dalam penelitian ini adalah penelitian deskriptif kualitatif yang mengarah pada pendeskripsian secara rinci dan mendalam mengenai kondisi tentang yang sebenarnya 
terjadi dan sesuai dengan yang ada di lapangan. Metode penelitian kualitatif menurut Sugiyono(2013: 9) adalah metode penelitian yang digunakan untuk meneliti pada kondisi objek yang alamiah, peneliti sebagai instrumen kunci, teknik pengumpulan data secara trianggulasi, analisa data bersifat induktif, dan hasil penelitian kualitatif lebih menekankan makna pada generalisasi.

Penelitian

lebih

menggunakan pendekatan

antarpersonal. Artinya selama proses penelitian, akan lebih banyak mengadakan kontak atau berhubungan langsung dengan santriwan-santriwati, pengurus pondok dan tokoh masyarakat di sekitar lokasi penelitian.

Sumber data di dalam penelitian kualitatif menurut Lofland (dalam Moleong, 2002: 112) ialah kata-kata, dan tindakan selebihnya adalah data tambahan seperti dokumen dan lain-lain. Sementara itu, Sugiyono (2013: 225) menyebutkan bahwa sumber data yaitu sumber data primer dan sumber data sekunder.Sumber data primer yaitu data yang langsung dari masyarakat baik yang dilakukan melalui wawancara, observasi dan alat lainnya.Sumber data sekunder yaitu sumber data yang berupa dokumen yang secara tidak langsung memberikan informasi kepada peneliti.

Penelitian ini dilaksanakan di Pondok Pesantren Darussalam Mekar Agung Desa Pucanganom, Kecamatan Kebonsari, Kabupaten Madiun selama empat bulan, yaitu pada Maret sampai dengan Juni 2015. Rincian kegiatan secara garis besar meliputi tahap persiapan, tahap pelaksanaan dan tahap penyelesaian. Teknik pengumpulan data dalam penelitian ini dilakukan dengan teknik observasi, wawancara, dan dokumentasi.

Teknik analisis data dalam penelitian ini menggunakan teknik analisis data interaktif. Menurut Miles dan Huberman (dalam Sugiyono, 2013: 246-253) analisis data interaktif mengemukakan bahwa aktivitas dalam analisis data kualitatif dilakukan secara interaktif dan berlangsung secara terus menerus sampai tuntas sampai akhir penelitian sehingga datanya jenuh. Rangkaian aktivitas yang dilakukan 
dalam proses analisis interaktif berbentuk interaksi antarkomponen yaitu reduksi data, penyajian data, dan penarikan kesimpulan dan verifikasi.

\section{HASIL DAN PEMBAHASAN}

Pondok

Pesantren

Darussalam Mekar Agung mempunyai peranan membentuk karakter mandiri pada santri. Peranan pondok pesantren dalam pembentukan karakter mandiri santri sangat banyak contohnya untuk bekal kehidupan sehari-hari kelak waktu sudah lulus dengan cara mengajarkan santri untuk mengelola sawah, kolam lele, dan lain-lain.

\section{Pembentukan}

karakter

mandiri ini dilakukan oleh pondok pesantren untuk membentuk para santriwan-santriwati yang lebih mandiri lagi, karena banyak kita ketahui di zaman sekarang banyak anak yang mempunyai sifat manja yang semua itu tidak baik untuk mereka kedepannya apa lagi anak tersebut beranjak dewasa dan memasuki masa mencari kerja. Yang pada kenyataannya mencari pekerjaan sekarang susahnya tidak karuan, maka dari itu pondok pesantren Darussalam Mekar Agung ini berperan untuk membentuk karakter mandiri anak.

Kemandirian yang dikembangkan di Pondok Pesantren Darussalam Mekar Agung yaitu kemandirian emosi, ekonomi, intelektual dan kemandirian social. Hal ini terbukti dengan adanya kegiatan-kegiatan yang dilakukan di Pondok Pesantren Darussalam Mekar Agung, yang dilakukan di dalam pondok maupun di lingkungan masyarakat.

Pembentukan karakter mandiri santri dilakukan dengan kegiatan-kegiatan yang bersifat individual seperti mencuci baju sendiri, membersihkan kamar tidur sendiri, masak sendiri bagi santriwan santriwati yang sudah dewasa. Untuk melatih santriwan-santriwati mandiri, juga didukung oleh kegiatankegiatan yang bersifat keorganisasian yang dapat dicontohkan dengan kegiatan seperti kepengurusan pondok, pramuka, OSIS di sekolah dan mengurus lahan pertanian, koperasi pondok, ternak sapi dan kolam lele yang dimiliki pondok pesantren serta mengikuti latihan keterampilan menjahit dan 
keterampilan pengrajin kayu pesantren serta mengikuti latihan

(meubel). Santriwan-santriwati selain keterampilan menjahit dan belajar agamanya yang sangat kental keterampilan pengrajin kayu juga diberikan keterampilan yang (meubel)

sekiranya dapat digunakan kelak Pondok

Pesantren kalau sudah lulus dari pondok pesantren.

\section{SIMPULAN}

Berdasarkan hasil penelitian, dapat disimpulkan tentang Pola Pembentukan Karakter Mandiri pada Pondok Pesantren Darussalam Mekar Agung Desa Pucanganom, Kecamatan Kebonsari, Kabupaten Madiun Tahun 2015. Pola pembentukan karakter mandiri anak yang dilakukan di pondok pesantren ini dilakukan dengan berbagai cara misalnya santri mencuci baju sendiri, membersihkan kamar tidur sendiri, masak sendiri bagi santriwan santriwati yang sudah dewasa. Untuk melatih santriwan-santriwati mandiri, juga didukung oleh kegiatankegiatan yang bersifat keorganisasian yang dapat dicontohkan dengan kegiatan seperti kepengurusan pondok, pramuka, OSIS di sekolah dan mengurus lahan pertanian, koperasi pondok, ternak sapi dan kolam lele yang dimiliki pondok 


\section{DAFTAR PUSTAKA}

Gemilang Subang. (2011). Pendidikan Karakter Mandiri, (online),

(http://subang-

gemilang.blogspot.com/, di unduh pada 01 Maret 2015)

Lexy J. Moleong. 2012. Metodologi Penelitian Kualitatif. Bandung: Remaja Rosdakarya.

Mizan dan Aniez. (2012). Pengertian Pondok Pesantren, (online), (http://www.perkuliahan.co m/pengertian-pondokpesantren/, di unduh pada 01 Maret 2015)

Naim Ngainun. 2012. Character Bulding: Optimalisasi Peran Pendidikan dalam Pengembangan Ilmu \& Pembentukan Karakter Bangsa. Jogjakarta: ARRUZZ Media

Octavia Lanny dkk. 2014. Pendidikan Karakter Berbasis Tradisi Pesantren. Jakarta: Rumah Kitab.

PPLWH. (2012). Sekilas Pondok Pesantren, (online), (http://pplwhsemarang.blogspot.com/201 2/10/sekilas-pondokpesantren.html? $\mathrm{m}=1$, diunduh 1 Maret 2015)

Sugiyono. 2013. Metode Penelitian Kuantitatif Kualitatif dan $R \& D$. Bandung: Alfabeta.
Undang-undang Nomor 20 Tahun 2003 Tentang Sistem Pendidikan Nasional.

Wardoyo Mangun Sigit. 2013. Pembelajaran

Konstruktivisme. Bandung: Alfabeta. 